\title{
Purification and properties of pectinesterase from soursop (Anona muricata) pulp
}

\begin{abstract}
Two forms of pectinesterase were purified using the techniques of ammonium sulphate fractionation, ion-exchange chromatography and gel filtration. PE I had a specific activity of approximately 4 units mgī 1 (43-fold), that of PE II was 6.4 units mgī 1 (229-fold). These pectinesterases (PE I and PE II) had approximate molecular weights of 29100 and 24100 , respectively, as estimated by gel filtration, and 31000 and 28000 , respectively, as estimated by sodium dodecyl sulphate polyacrylamide electrophoresis. The optimum temperature for enzyme activity was shown to be $60{ }^{\circ} \mathrm{C}$ for both PE I and PE II. The activation energies of PE I and PE II were calculated as $36 \mathrm{~kJ}$ molī 1 and $42 \mathrm{~kJ}$ molī 1, respectively. The optimum $\mathrm{pH}$ values for both pectinesterases lie within the range 7.0I 8.0. The $\mathrm{Km}$ value for PE I was $0.52 \mathrm{mg} \mathrm{mlī} 1$ and $0.0843 \mathrm{mg} \mathrm{mlī} 1$ for PE II. PE I had a maximum velocity (Vmax) of 154 عmol mgī 1 minī 1, and PE II a Vmax of 726 عmol mgī 1 minī 1.
\end{abstract}

Keyword: Pectinesterase; Purification; Anona muricata 